J. Clin. Chem. Clin. Biochem.

Vol. 21, 1983, pp. 779-782

\title{
Insulin Binding to Erythrocytes before and after Changing from Porcine to Biosynthetic Human Insulin in Children with Type-I Diabetes
}

\author{
By R. Zick, B. Meyer
}

Arbeitsbereich Diabetologie des Zentrums für Innere Medizin und Dermatologie, Medizinische Hochschule Hannover,

W. von Schütz

Städtische Kinderklinik Hannover,

W. Holle, A. Dwenger

Abteilung für Klinische Biochemie, Medizinische Hochschule Hannover,

\section{H. J. Mitzkat}

Arbeitsbereich Diabetologie des Zentrums für Innere Medizin und Dermatologie, Medizinische Hochschule Hannover and

\section{P. Hürter}

Städtische Kinderklinik Hannover

(Received January 13/August 26, 1983)

Summary: The binding of $\left[{ }^{125} I\right]$ insulin to isolated erythrocytes from diabetic children $(n=27)$ before (group a) as well as one and five months after changing from porcine to biosynthetic human insulin (groups b and c) was investigated. An analysis of variance of the binding parameters, determined by a nonlinear regression procedure, yielded statistically significant differences between the receptor affinities $K_{\mathrm{a}}$ as well as between the receptor concentrations $X_{o}$ of the groups $a$ and $b$; $a$ and $c$ and $b$ and $c$.
$\mathrm{K}_{\mathrm{a}} \pm \mathrm{s}_{\mathrm{K}_{\mathrm{a}}}\left(10^{8} \mathrm{l} / \mathrm{mol}\right)$
$0.068 \pm 0.028$
$0.043 \pm 0.030$
c
$24.0 \pm 4.5$
$0.029 \pm 0.007$
a
$11.6 \pm 7.6$
b
$19.3 \pm 10.0$

The results suggest that the change from porcine insulin to biosynthetic human insulin induces a short-term as well as long-term increase in the affinity, and a decrease in the concentration of the erythrocyte insulin receptors.

Insulinbindung an Erythrocyten vor und nach Umstellung von Schweine-auf biosynthetisches Humaninsulin bei Kindërn mit Typ-I-Diabetes

Zusammènfassung: D̈ie Bindung von [ $\left.{ }^{125}\right]$ Insulin an Erythrocyten wurde bei diabetischen Kindern $(\mathrm{n}=27)$ vor (Gruppe a), einen sowie fünf Monate nach Umstellung von Schweineinsulin auf biosynthetisches Humaninsulin (Gruppen b und c) untersucht. Aus einer Varianzanalyse der mit einem nichtlinearen Regressionsverfạhren ermittelten Bindungskenngrößen ergaben sich statistisch signifikante Unterschiede sowohl zwischen den Rezeptoraffinitäten $\mathrm{K}_{\mathrm{a}}$ als auch zwischen den Rezeptorkonzentrationen $\mathrm{X}_{\mathrm{o}}$ der Gruppen $\mathrm{a}$ und $\mathrm{b}, \mathrm{a}$ und $\mathrm{c}$, und $b$ und $c$. 


$\begin{array}{llcc} & \mathrm{a} & \mathrm{b} & \mathrm{c} \\ \mathrm{K}_{\mathrm{a}} \pm \mathrm{s}_{\mathrm{u}}\left(10^{8} \mathrm{l} / \mathrm{mol}\right) & 11,6 \pm 7,6 & 19,3 \pm 10,0 & 24,0 \pm 4,5 \\ \mathrm{X}_{\mathrm{o}} \pm \mathrm{s}_{\mathrm{X}}(\mathrm{nmol} / \mathrm{l}) & 0,068 \pm 0,028 & 0,043 \pm 0,030 & 0,029 \pm 0,007\end{array}$

Die Resultate zeigen, daß die Umstellung von Schweineinsulin auf biosynthetisches Humaninsulin sowohl kurz- als auch langfristig eine Zunahme der Affinität und eine Abnahme der Konzentration der erythrocytären Insulinrezeptoren bewirkt.

\section{Introduction}

With the introduction of biosynthetic human insulin into diabetes therapy, the question of the biological activity of this new insulin arises, in particular in comparison with the insulin preparations used so far.

When analysing the insulin effect, the first step consists in the binding to specific receptors on the cell surface of the single target organs $(1,2)$. This coupling may be modulated by short-term change in the receptor affinity and by long-term variation of the receptor concentration $(3,4)$.

In the in vitro studies to date, which only included short-term alterations, no differences between the binding properties of biosynthetic human insulin and other insulins were revealed $(5,6,7)$.

Therefore it was the objective of our investigations to detect in vivo predominantly longer-term changes in the binding behaviour of insulin to receptors after switching from pork insulin to biosynthetic human insulin.

The model of the erythrocyte insulin receptor was selected, because the erythrocyte is subject to receptor alterations similar to those occurring in the peripheral tissues, and the small blood volume required can be technically and psychologically justified in clinical studies.

The following data are the results of investigations performed one and five months after switching the insulin preparation.

\section{Materials and Methods \\ Subjects}

Insulin binding to erythrocytes was measured in 27 children $(\$ 18, \delta 9)$ aged between 12 and 18 years $(\bar{x} \pm s, 15.33 \pm 1.76$ years) with type-I-diabetes. The duration of diabetes was between 2.7 und 14.9 years $(\bar{x} \pm s, 7.48 \pm 2.19$ years $)$, and the mean age of diabetes manifestation was 8.2 years.

All children received two insulin injections per day, and the daily insulin requirement was more than $0.5 \mathrm{IU} / \mathrm{kg}$ body weight $(0.86 \pm 0.23, x \pm s)$; i.e., all patients were in a phase of postremission defined by Akerbloom (8).
Prior to the change (group a) all children had received an individual mixture of regular and NPH porcine insulin (Nordisk). They were transferred to an individual mixture of regular and NPH biosynthetic human insulin (Lilly): The binding studies were repeated one month (group b) as. well as 5 months (group c) after changing the insulin preparation.

The body height of all children was between the 25th and 75th percentile; all children had normal weight corresponding to their heights. Liver diseases and renal diseases as well as disturbances of blood formation had been excluded by preliminary examiñations.

\section{Insulin binding studiès}

12 hours after the last insulin injection and the last food ingestion, approximately $10 \mathrm{ml}$ of heparinized whole blood were taken by venipuncture.

Insulin binding was performed according to the procedure of Gambhir (9) with slight modifications (10). Isolated erythrocytes $\left(3.5-4.5 \times 10^{12} \AA\right)$ were incubated with porcine [ $\left.{ }^{125} \mathrm{I}\right]$ insulin $(0.05 \mathrm{nmol} / \mathrm{l})$ and unlabeled porcine insulin $(0.09-174 \mathrm{nmol} / \mathrm{l})$ at $15^{\circ} \mathrm{C}$ for 3 hours.

Analytical procedures

Free insulin and daily $\mathrm{C}$-peptide excretion in urine were determined radioimmunologically $(11,12)$. $\mathrm{HbA}_{1 \mathrm{c}}$ values in blood were measured according to l.c. (13).

\section{Calculation procedures}

For parameter extraction a nonlinear regression procedure was applied which is based on an algorithm indicated by Marquardt (14). The insulin receptor affinity $\left(\mathrm{K}_{\mathrm{a}}\right)$, the insulin receptor concentration $\left(X_{0}\right)$, and the nonspecific binding $(U)$ were iteratively determined for the one-class binding model via the minimization of the sum of the squares of error with the aid of a HP $9835 \mathrm{~A}$ computer.

For statistical analyses, parametric procedures (t-test for paired data) were applied in cases of normal distribution of the data; otherwise nonparametric procedures (Wilcoxon-test) were employed.

\section{Results}

One month after changing from porcine insulin to biosynthetic human insulin the insulin receptor affinity had significantly increased from 11.6 to $19.3 \times$ $10^{8} \mathrm{l} / \mathrm{mol}$ ( $\left.\mathrm{p}<0,001\right)$.

After another period of 4 months the receptor affinity increased to $24.0 \times 10^{8} \mathrm{l} / \mathrm{mol}$, thus demonstrating an increase of $105.7 \%$ in comparison with the receptôr affinity prior to switching the insulin therapy (fig. 1, tabs. 1 and 2). 


\section{Erstmals das umfassende photometrische in vitro-Programm zur Schilddrüsendiagnostik von Boehringer Mannheim}

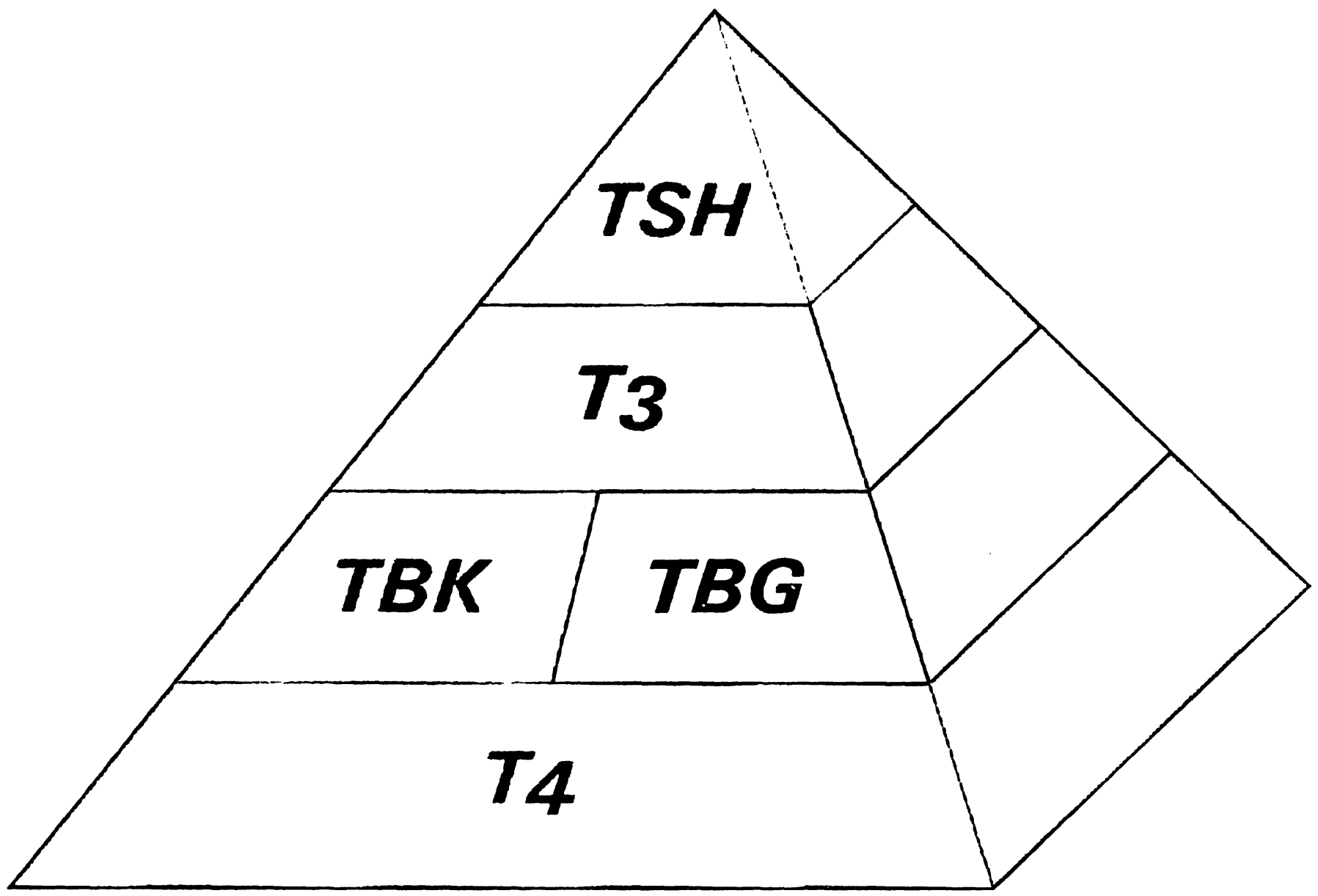

Für Ihr Labor Enzymimmunoassays in coated tube-Technik:

- hohe Spezifität, Empfindlichkeit und Präzision

- kurze Inkubationszeit (z. B. TSH $3 \times 1$ Std.)

- einfache Handhabung

- lange Haltbarkeit der Reagenzien

- keine Radioaktivität

- automatișche Auswertung mit: Enzymun-Test ${ }^{\circledR}$-System ES 11

Boehringer Mannheim bietet zur Schilddrüsendiagnostik erfahrene Fachberater, umfassende Informationsbroschüren und ein vielseitiges Fortbildungsprogramm.
Enzymun-Test ${ }^{\circledR}$ TBG

Bestell-Nr. 249432

Enzymun-Test ${ }^{\circledR}$ TBK

Bestell-Nr. 249416

Enzymun-Test ${ }^{\circledR}$ T3

Bestell-Nr. 204528

Enżymun-Test ${ }^{\circledR}$ T 4

Bestell-Nr. 204510

neu

Enzymun-Test ${ }^{\circledR}$ TSH

Bestell-Nr. 736082
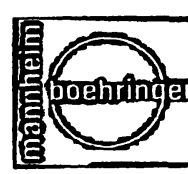

Boehringer Mannheim GmbH Abt. M-DPI Postfach 31012 6800 Mannheim 31 


\section{Walter de Gruyter Berlin. New York}

\section{J. Büttner (Editor)}

\section{History of Clinical Chemistry}

1983. $18 \mathrm{~cm} \times 26 \mathrm{~cm}$. 91 pages with illustrations. Hardcover. DM 98,-; approx. US \$44.75 ISBN 3110089122

Clinical Chemistry is a special discipline of medicine which, due to its close relationship both to medicine and to chemistry, is of particular interest to the historian of science.

This "History of Clinical Chēmistry" is based on a modern outloọk on the history of science. Since the investigation of the history of clinical chemistry is still in progress, the book is divided into eight separate contributions, written primarily by historians of science, which together provide a good coverage of the history of Clinical Chemistry in the nineteenth century.

The book is written entirely in English and will therefore appeal to an international readership. Each contribution is provided with numerous notes and references.

\section{Contents}

Johannes Büttner - Introduction - Nikolaus Mäni - The historical background of Clinical Chemistry - Joseph S. Fruton - Biochemistry and Clinical Chemistry. A retrospect - Erika Hickel . The emergence of Clinical Chemistry in the 19th century. Presuppositions and consequences " Johannes Büttiner - Johann Joseph von Scherer (1814-1869). A commentary on the early history of Clinical Chemistry · Hans H. Simmer - Medicine and Chemistry around the middle of the 19th century in Erlangen: Eugen Franz Freiherr von Gorup-Besanez (1817-1878) · Johannes Büttner - Evolution of Clinical Enzymology - Johannes Büttner · Relationships between Clinical Medicine and Clinical Chemistry, illustrated by the example of the German-speaking countries in the late 19th century - Wendell T. Caraway - Major developments in clinical chemical inștrumentation. 


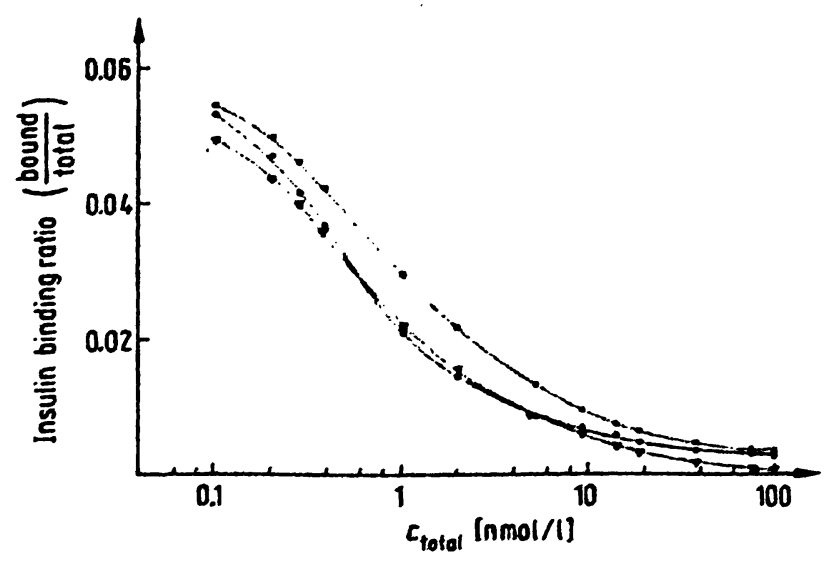

Fig. 1. Specific insulin binding to human erythrocytes $\left(4 \times 10^{12} / 1\right)$ in diabetic children before (⿴囗十), one month $(\Delta)$, and five months $(\bullet)$ after changing insulin treatment from porcine to biosynthetic human insulin. Means of $\left[{ }^{125} 1\right.$ linsulin binding $(B / T)$ in dependence on the total insulin concentration (nmol/l) corrected by iterated non-specific binding.

In contrast, the insulin receptor concentration decreased significantly within one month from 0.068 to $0.043 \mathrm{nmol} / 1(\mathrm{p}<0.001)$. The second control examination showed a further decrease in the receptor concentration to $0.029 \mathrm{nmol} / \mathrm{l}$. This represents a $57.3 \%$ decrease compared with the receptor concentration in patients under treatment with porcine insulin (fig. 1, tabs. 1 and 2).

The metabolic control of the diabetic children did not exhibit any significant alterations within the observation period of 5 months. The $\mathrm{HbA}_{\mathrm{lc}}$ values were in the range of $0.091,0.091$, and 0.089 (fraction of total haemoglobin) (tab. 3).

The endogenous insulin secretion decreased from 0.83 to $0.29 \mathrm{nmol} / 24 \mathrm{~h}$ on average; the differences in the C-peptide excretion in the 24-hour urine, however, were statistically not significant (tab. 3).
Tab. 1. Insulin receptor affinity $\left(K_{a} \pm S_{K_{0}}\right)$ and concentration $\left(X_{0} \pm s_{x_{0}}\right)$ for three groups of children

\begin{tabular}{lll}
\hline & $\begin{array}{l}\text { Affinity }\left(K_{a}\right) \\
(\bar{x} \pm s) \\
\left.(1)^{8} / / m o l\right)\end{array}$ & $\begin{array}{l}\text { Concentration }\left(X_{0}\right) \\
(\hat{x} \pm s) \\
(\mathrm{nmol} / 1)\end{array}$ \\
\hline $\begin{array}{l}\text { Group a } \\
\text { (porcine insulin) }\end{array}$ & $11.6 \pm 7.6$ & $0.068 \pm 0.028$ \\
$\begin{array}{l}\text { Group b } \\
\text { (biosynthetic human } \\
\text { insulin, one month) }\end{array}$ & $19.3 \pm 11.0$ & $0.043 \pm 0 .(1) 30$ \\
$\begin{array}{l}\text { Group c } \\
\text { (biosynthetic human } \\
\text { insulin, five months) }\end{array}$ & $24.0 \pm 4.5$ & $0.029 \pm 0.0107$ \\
\hline
\end{tabular}

Tab. 2. Statistical comparison of insulin receptor affinities $\left(K_{a}\right)$ and concentrations $\left(X_{0}\right)$ for three groups of children (n.s. = not significant).

\begin{tabular}{cll}
\hline Groups & $\mathrm{a}$ & $\mathrm{b}$ \\
\hline $\mathrm{c} \mathrm{K}_{\mathrm{a}}$ & $\mathrm{p}<0.0(1)$ & $\mathrm{p}<0.02$ \\
$\mathrm{X}_{\mathrm{a}}$ & $\mathrm{p}<0.001$ & $\mathrm{p}<0.05$ \\
$\mathrm{~b} \mathrm{K_{ \textrm {a } }}$ & $\mathrm{p}<0.001$ & \\
$\mathrm{X}_{\mathrm{a}}$ & $\mathrm{p}<0.001$ & \\
\hline
\end{tabular}

\section{Discussion}

In contrast to all reports to date $(5,6,15)$, we were able to demonstrate that the binding behaviour of the insulin receptors changed characteristically after switching from porcine insulin to biosynthetic human insulin: Within 4 weeks the affinity constant increased by $65 \%$ and the receptor concentration decreased by $36 \%$. The second control investigation, 5 months after the switch, confirmed these results and showed a further increase of the affinity constants by

Tab. 3. Fasting free insulin concentration, $\mathrm{HbA}_{1 c}$ values, daily insulin requirement and daily urinary $\mathrm{C}$-peptide excretion for three groups of diabetic children.

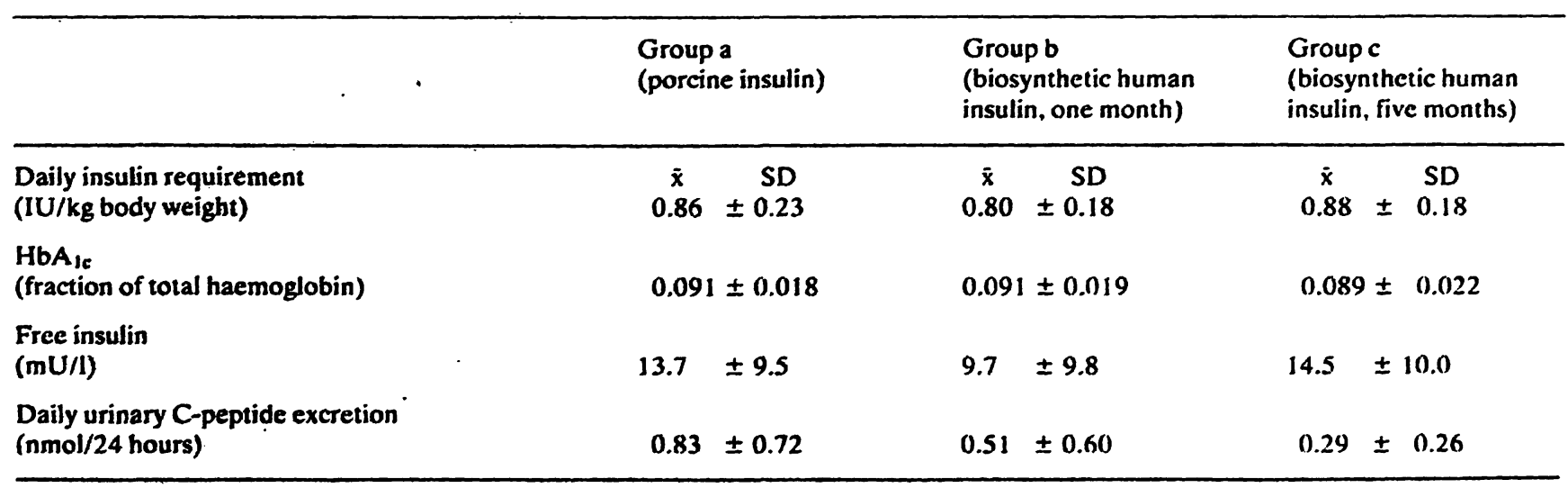


$24 \%$ as well as a decrease of the receptor concentration by $33 \%$. We could exclude a deterioration of metabolic control (16) as well as an increase in the daily insulin requirement (17) as a cause for the change in the binding behaviour in the children.

The lack of agreement with previously published results may possibly be explained by the fact that all in vitro binding studies could only exclude short-term changes in the binding behaviour and therefore are not fully comparable with our study of 5 months du= ration; the only in vivo study on the binding behaviour was performed with semisynthetic human insulin on monocytes from only 6 adult type-I-diabetics (15).

Within 4 weeks after switching to the treatment with biosynthetic human insulin, the affinity constant increased by $65 \%$ and the receptor concentration decreased by $36 \%$. Since during the same period of time only about $30 \%$ of the erythrocytes were newly formed, this portion of new erythrocytes must have been equipped with few, but unusually high-affinity receptors, in order to give an explanation for the increase in the affinity constants in the erythrocyte population investigated. Furthermore, this effect should have induced after 5 months comparatively much higher increases in the affinity as well as corresponding decrease in the concentration than the data obtained indicate.

The relatively rapid increase in affinity and the decrease in the receptor concentration after the switch to biosynthetic human insulin therefore could not be explained by the new synthesis of a higher-affinity receptor; it had to be caused by a direct or by a signal molecule-mediated indirect modulation mechanism in which the biosynthetic human insulin interferes in a modulating fashion at the posttranslational level.

Whether this process consists in the conformative alteration of an uniform insulin receptor or in the selectioning of a high-affinity receptor species cannot be determined since a multireceptor model as well as the actually discussed negative cooperativity model (18) or a two-receptor model (high affinity / low capacity - low affinity / high capacity) serve equally well for the interpretation of the binding data.

\section{Acknowledgement}

We thank Dr. F. Enzmann (Eli Lilly, Bad Homburg) for the generous support of these investigations.

\section{References}

1. Gavin, J. R., Roth, J., Jen, P. \& Freychet, P. (1972) Proc. Nat. Acad. Sci. USA 69, 747-751.

2. De Pirro, R., Bertoli, A., Greco, A. A. V., Fusco, A. \& Lauro, R. (1979) Acta Endocrinol. (Kbh.) Suppl. 225, 310.

3. Koltermann, O. G., Greenfield, M., Reaven, G. M., Saekow, M. \& Olefsky, J. M. (1979) Diabetes 28, 731-736.

4. Olefsky, J. M. (1976) J. Clin. Invest. 38, 1450-1460.

5. Bachmann, W., Sieger, C., Lacher, F. \& Lotz, N. (1981) Diabetes Care 4, 215-219.

6. De Meyts, P., Halban, P. H. \& Hepp, D. (1981) Diabetes Care 4, 144-146.

7. Schlüter, K. J. (1982) In: Neue Insuline (Petersen, K. G. Schlüter, K. J. \& Kerp, L. eds.), Freiburger Graphische Betriebe, Freiburg, p. 111-117.

8. Åkerbloom, H. K. (1980) Acta Paediatr. Belg. 33, 66.

9. Gambhir, K. K., Archer, J. A. \& Bradley, C. J. (1978) Diabetes $27,701-708$.

10. Dwenger, A., Mitzkat, H. J., Holle, W., Tost, P. \& Trautschold, I. (1982) J. Clin. Chem. Clin. Biochem. 20, 273-279.
11. Nakagawa, S., Nakayạma, H. \& Sasaki, T. (1973) Diabetes $22,590-600$.

12. Zick, R., Hürter, P., Lange, P. \& Mitzkat, H. J. (1982) Monatsschr. Kinderheilkd. 130, 209-214.

13. Holloway, C. J., Schlanstedt-Jahn, U., Haeger, I., Mitzkat, H. J. \& Trautschold, I. (1980) In: Electrophoresis (Radola, B. J. ed.), de Gruyter, Berlin, p. 669-675.

14. Dwenger, A., Holle, W., Tost, P. \& Trautschold, I. (1983) J. Clin. Chem. Clin. Biochem. 21, 721-729.

15. Schernthaner, G. (1982) In: Neue Insuline (Petersen K. G., Schlüter, K. J. \& Kerp, L. eds.) Freiburger Graphische Betriebe, Freiburg, p. 140-148.

16. Eaton, $\vec{R}$. P., Galagan, R., Kaufmann, E., Allen, R. C., Russel, L. \& Miller, F. (1981) Diabetes Care 4, 299-305.

17. Gavin, J. R., III, Roth, J. \& Neville, D. M. (1974) Proc. Nat. Acad. Sci. USA $711,84-88$.

18. De Meyts, P., Roth, J., Neville, D. M., Gavin, J. R̈., IIII, Lesniak, M. A. (1973) Biochem. Biophys. Res. Commun. 55, 154-161

Dr. med. Reinhard Zick

Zentrum für Innere Medizin und Dermatologie Arbeitsbereich Diabetologie

Medizinische Hochschule Hannover

Konstanty-Gutschow-Str. 8

D-3000' Hannover 61 